\title{
Association of the Red Reflex in Newborns with Neonatal Variables ${ }^{1}$
}

\author{
Adriana Sousa Carvalho de Aguiar ${ }^{2}$ \\ Lorena Barbosa Ximenes ${ }^{3}$ \\ Ingrid Martins Leite Lúcio ${ }^{4}$ \\ Lorita Marlena Freitag Pagliuca ${ }^{5}$ \\ Maria Vera Lúcia Moreira Leitão Cardoso ${ }^{6}$
}

The aim of this study was to investigate the results of the red reflex test and to associate these results with neonatal variables. This descriptive study was conducted with 190 newborns in a public maternity hospital. A total of 187 infants presented no alteration and three presented suspect results. Different shades of reflex color were observed: 50 (26.3\%) presented red; 34 (17.9\%) orange-red, 92 (48.4\%) orange, $11(5.8 \%)$ light yellow and three $(1.6 \%)$ milky white spots. Statistically significant associations between the color gradient instrument and neonatal variables were found: weight $(p=0.03)$, gestational age $(p=0.019)$ and oxygen therapy $(p=0.024)$. Nurses trained to practice and evaluate this test may become professionals in the potential for the prevention of childhood blindness.

Descriptors: Eye Health; Blindness; Pediatric Nursing; Neonatal Screening.

${ }^{1}$ Paper extracted from to Undergraduate Nursing Program Thesis "Prevenção da cegueira infantil atravé do teste do reflexo vermelho", presented to Departamento de Enfermagem, Universidade Federal do Ceará, CE, Brasil. This research was supported by Conselho Nacional de Desenvolvimento Científico e Tecnológico (CNPq), process \# 620117/2008-7.

${ }^{2}$ RN, Master's Student in Nursing, Departamento de Enfermagem, Universidade Federal do Ceará, CE, Brasil. Scholarship holder of Fundação Cearense de Apoio ao Desenvolvimento Científico (FUNCAP). E-mail: adrianaufc@gmail.com.

${ }^{3}$ RN, Ph.D. in Nursing, Associate Professor, Departamento de Enfermagem, Universidade Federal do Ceará, CE, Brazil. E-mail: Ibximenes@yahoo.com.br.

${ }^{4}$ RN, Ph.D. in Nursing, Full Professor, Faculdade Integrada da Grande Fortaleza, CE, Brazil. E-mail: ingrid@fgf.edu.br.

${ }^{5}$ RN, Ph.D. in Nursing, Full Professor, Departamento de Enfermagem, Universidade Federal do Ceará, CE, Brazil. E-mail: pagliuca@ufc.br.

${ }^{6}$ RN, Ph.D. in Nursing, Associate Professor, Departamento de Enfermagem, Universidade Federal do Ceará, CE, Brazil. E-mail: cardoso@ufc.br.

Corresponding Author:

Adriana Sousa Carvalho de Aguiar

Rua Alexandre Baraúna, 1115

Bairro: Rodolfo Teófilo

CEP: 60430-160 Fortaleza, CE, Brasil

E-mail: adrianaufc@gmail.com 


\section{Associação do reflexo vermelho em recém-nascidos com variáveis neonatais}

Objetivou-se investigar o resultado do teste do reflexo vermelho, conhecido como teste do olhinho, e associar as impressões do reflexo com variáveis neonatais. Este é um estudo descritivo, quantitativo, realizado com 190 recém-nascidos de uma maternidade pública, dos quais 187 apresentaram resultado não alterado e três suspeitos. Observaram-se diferentes nuances de coloração do reflexo: em $50(26,3 \%)$ a coloração do reflexo apresentou-se vermelha; 34 (17,9\%) laranja-avermelhado; 92 (48,4\%) alaranjado; $11(5,8 \%)$ amarelo claro e três $(1,6 \%)$ com manchas esbranquiçadas. Encontraramse associações estatisticamente significantes entre o instrumento gradiente de cores e variáveis neonatais: peso $(p=0,03)$, idade gestacional $(p=0,019)$ e oxigenoterapia $(p=0,024)$. Enfermeiros capacitados para prática e avaliação desse teste podem se tornar profissionais em potencial para a prevenção da cegueira infantil.

Descritores: Saúde Ocular; Cegueira; Enfermagem Pediátrica; Triagem Neonatal.

\section{Asociación del reflejo rojo con variables neonatales en recién nacidos}

Se objetivó investigar el resultado de la prueba del reflejo rojo, conocido como prueba del ojito, y asociar las impresiones del reflejo con variables neonatales. Se trata de un estudio descriptivo, cuantitativo, realizado con 190 recién nacidos de una maternidad pública; de los cuales 187 presentaron resultados no alterados y tres sospechosos. Se observaron diferentes matices de coloración del reflejo: en $50(26,3 \%)$ se presentó rojo; 34 (17,9\%) naranja rojizo; 92 (48,4\%) anaranjado; 11 (5,8\%) amarillo claro y tres $(1,6 \%)$ con manchas blanquecinas. Se encontraron asociaciones estadísticamente significativas entre el instrumento gradiente de colores y las variables neonatales: peso $(p=0,03)$, edad de gestación $(p=0,019)$ y oxigenoterapia $(p=0,024)$. Enfermeros capacitados para la práctica y evaluación de esa prueba pueden tornarse profesionales en potencial para la prevención de la ceguera infantil.

Descriptores: Salud Ocular; Ceguera; Enfermería Pediátrica; Tamizaje Neonatal.

\section{Introduction}

Studies indicate that approximately $75 \%$ of cases of blindness are preventable, which would imply an improvement in quality of life, and a considerable reduction in the economic and social costs of specialist treatment and rehabilitation programs ${ }^{(1)}$.

The red reflex test (RRT) constitutes a great ally when considering measures designed to prevent childhood blindness. The use of the red reflex as a screening test, inserted in several scenarios of nursing care for the newborn (NB) i.e. in the hospital environment or in primary health care, contributes to the early identification of vision problems, making effective interventions possible ${ }^{(2)}$.

This test constitutes part of the physical examination, is low cost, of simple application and efficient, preferably indicated in the first days of the life of the infant ${ }^{(3-4)}$. It searches for leukocoria as the main clinical sign, a condition in which the pupil presents a white color, commonly seen in congenital cataracts, in retinoblastomas and in advanced stage retinopathy of

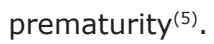


The importance of this test is to evaluate the quality of the transparent media of the eye, with the details of the internal structures being evaluated through fundoscopy by the ophthalmologist. When the focus of the ophthalmoscope light is aligned directly along the visual axis of the pupillary space, a homogeneous orange - reddish glow is reflected. This indicates that the internal structures of the eye (cornea, crystalline lens and vitreous) are transparent, allowing the retina to be affected by light in a normal way. When there is any alteration, it is not possible to observe the reflex or its quality is $\operatorname{bad}^{(3,6-7)}$.

The coloration of the reflex observed may be influenced by several factors including, the incidence of light, the pigmentation and the stage of retinal development. Likewise, other variables may be related such as, the use of oxygen, the gestational age of the newborn and its position at the time of the test, which effects the alignment of the visual axis ${ }^{(8)}$. Therefore it is necessary to know all these variables, since, in addition to being considered risk factors for the development of vision problems, they can be related to the result found in the red reflex test.

In one study, where the aim was to train nurses of a maternity hospital to perform the red reflex test, through the application of an educational method, 240 examinations were conducted. It was observed that the sector that favored the largest number of evaluations of this test was the low-risk neonatal unit, with 101 NBs evaluated $(42 \%)$, followed by the rooming-in unit with $60(25 \%)$ and the normal delivery center with 51 (21\%). These were considered propitious environments due to the ease of leaving the infants in darkness, due to them being sectors where the NB is in a satisfactory general condition and due to them making prior contact possible with the mothers in order to offer guidance. In addition, the routine of these units allowed the investigation of the neonatal history in the medical records. Of the different sectors, the one with the lowest number of evaluations was the high-risk neonatal unit (1.7\%), due to the unstable health status of the newborn ${ }^{(9)}$

It is noteworthy that literature regarding the ocular health of the NB with emphasis on detection of vision problems is scarce and the contents related to this thematic are barely addressed in the disciplines of the undergraduate courses in Nursing(2).

However, the use of the red reflex test as a compulsory routine is growing. Through initiatives of the Ministry of Health and Health Secretariats of the States, this test has established itself gradually as a strategy for the promotion of ocular health that requires commitment and multidisciplinary participation to reduce avoidable blindness. To this end, the need is highlighted for the preparation and training of human resources, which arise from isolated initiatives in some Brazilian municipalities, through research and education for physicians (pediatricians, neonatologists, ophthalmologists) and nurses $(5,10)$

This study aimed to investigate the outcome of the red reflex test in newborns and to associate the appearance of the visualized reflex with neonatal variables.

\section{Methods}

This is a descriptive study with a quantitative approach, developed in a large Public Maternity Hospital, a reference center for the city of Fortaleza and the State of Ceará. Data collection was conducted from November 2006 to February 2007.

To calculate the sample size, the variable "ocular alteration or suspected of ocular disease" was elected, calculated with an prevalence of approximately $10 \%{ }^{(11)}$ The formula for finite populations was employed:

$$
\mathrm{n}=\frac{\mathrm{t}^{2}{ }_{5 \%} \times \mathrm{P} \times \mathrm{Q} \times \mathrm{N}}{\mathrm{e}^{2}(\mathrm{~N}-1)+\mathrm{t}^{2}{ }_{5 \%} \times \mathrm{P} \times \mathrm{Q}}
$$

Key: $\mathbf{t}$ is the value of the Student's $t$ distribution $\left(t_{5 \%}=1.96\right) ; \mathbf{P}$ is the prevalence of children with ocular alteration $(P=10 \%) ; Q=100 \%-P$, i.e. $Q=90 \%)$; $e$ is the sampling error $(e=4 \%) ; \mathbf{N}$ is the population size. Considering that the collection occurred over a four month period and that there are an average of 600 births per month, based on data provided by the institution where the research took place, then $\mathrm{N}=2400$. The sample size was $190(n=190)$.

The inclusion criteria were NBs hospitalized in the Neonatal Unit of low and medium risk, the "Kangaroomother" ward and the Rooming-in unit, since these NBs did not present unstable clinical conditions and handling restrictions, as for example, infants in incubators, intubated or on mechanical ventilation.

A structured form was used as a means of collecting data, composed of variables related to neonatal history (weight, gestational age, therapeutics use, conditions at birth) and a monocular ophthalmoscope for the performance of the red reflex test. The completion of the data form occurred by consulting the records in the charts of the NB. 
To assist in the evaluation of the examination and description of the ocular reflex found in the infants an instrument called the red reflex test color gradient was used, composed of shades of color distributed in gradients of red, orange and yellow, which vary in intensity (light to dark) and appearance (homogeneous, the presence or absence of mottling or milky white spots). Every shade of color presented in the instrument is assigned a code for identification, so that variations in the red color of the ocular reflex are grouped into R1 to R18, orange into $L 1$ to $L 21$ and yellow into $A 1$ to $A 16$.

The color gradient was intended to facilitate the registration and description of the characteristics of the reflex visualized in the test, making them the closest to the findings observed by the examiner using an ophthalmoscope.

This instrument was developed from the authors' experiences with the red reflex test, which demonstrated the need to create a resource that would be used to assist in the identification and comparison with the reflex found in the examination, as there are color variations of the reflex within the range of normality, which are not necessarily red, but that can be considered unchanged. Through the records of the appearances found as result of this test the red reflex test color gradient instrument was created, which has been perfected ${ }^{(2,9,12)}$.

The method for applying the red reflex test used in this study was based on a structured model created by an author who used it to train nurses in the field of Neonatology, as part of his doctoral thesis( ${ }^{(9)}$.

In this study the following terms were adopted: normal, altered, and suspect to classify the reflex visualized in the test, highlighting the observation "presence or absence of leukocoria". The reflexes considered suspect or altered were referred for specialized evaluation by an ophthalmologist partner of the research group.

The data were tabulated in EXCEL, described and analyzed using the software SPSS version 11.0 and based on descriptive statistics, using absolute and relative frequency, and presented in the form of tables. The findings encountered in the red reflex test and identified in the color gradient instrument were associated with neonatal history variables (weight, gestational age, conjunctivitis, use of oxygen therapy, of phototherapy and blood transfusion) adopting the $\chi^{2}$ test and the maximum verisimilitude method. For all tests the significance level was set at $95 \%$.

The study followed the ethical considerations laid out in resolution $196 / 86$ of the National Health
Council $^{(13)}$ and was approved by the Ethics Committee of the Institution in which it was performed, through the official notice No. 130/06 and protocol No. 28/06. The mothers or guardians of the NBs were informed of the study aims and signed the Terms of Free Prior Informed Consent authorizing the vision evaluation of their child.

\section{Results}

Of the total newborns evaluated using the red reflex test, in 187 (98.42\%) a normal, homogeneous, reflex was observed, with leukocoria absent, presenting the following color variations: $92(48.42 \%)$ orange, 50 $(26.32 \%)$ red; $34(17.89 \%)$ orange-red and $11(5.79 \%)$ light yellow.

Only three $(1.58 \%)$ of the newborns presented a suspect reflex. For these, besides the relevance of their life histories and health conditions, a non-standard reflex coloration was noticed, prominently yellow with lighter spots (milky white) in the center. These infants, considered at risk, were included in the retinopathy of prematurity screening and treatment program of the institution. Table 1, below, presents the result and description of the reflex, regarding the color appearance, found in the test.

Table 1 - Distribution of newborns (NBs) concerning the result and the description of the color variations of the red reflex test (RRT), Ceará, Brazil, 2007

\begin{tabular}{lcc}
\hline \multicolumn{1}{c}{ Variables } & F & $\%$ \\
\hline Result of the RRT & & \\
$\quad$ Normal reflex & 187 & 98.42 \\
$\quad$ Suspect reflex & 3 & 1.58 \\
Color variations of RRT & & \\
$\quad$ Orange & 92 & 48.42 \\
Red & 50 & 26.32 \\
Orange-red & 34 & 17.89 \\
Light Yellow & 11 & 5.79 \\
$\quad$ Yellow with milky white spots & 3 & 1.58 \\
Comparison of the reflex color between the eyes & & \\
$\quad$ Similar & 164 & 86.32 \\
Differences in intensity & 26 & 13.68 \\
\hline $\mathrm{n}=190$ & &
\end{tabular}

Comparing the coloration intensity of the ocular reflex between the pupils there were slight differences sometimes in the right eye, sometimes in the left eye.

The infants examined presented various shades of ocular reflex color, which were described and recorded with the aid of the RRT color gradient instrument. These results were then grouped into four categories, denominated Grads, which included the variations of the reflexes visualized in the test and identified in the gradient. 
Thus, grouped in the category Grad 1 were the shades of red of the ocular reflex observed and were identified as R1, R2, R4 and R6 in the RRT color gradient instrument. In the Grad 2 category, the color orange-red identified by L1 and L17 and in the Grad 3 category the variations of the color orange of the reflex encountered in the test, represented by L2, L4, L6, L9, L12 and L18 in the gradient. These three categories represented the variations in color of RRT normality. Grouped in the Grad 4 category were the shades of yellow (A1, A3) of the reflex observed, which in some cases, depending on the history of the neonate, may be present without alterations. However, this category also included the reflex color of yellow with milky white spots at the center (A9), found in the test and considered suspect.

Table 2 - Association between the red reflex test color gradient instrument and the neonatal variables, Ceará, 2007

\begin{tabular}{|c|c|c|c|c|c|c|c|c|c|}
\hline \multirow{3}{*}{ Neonatal variables } & \multicolumn{8}{|c|}{ Gradient of colors } & \multirow{3}{*}{$\frac{\chi^{2}}{\mathbf{p}}$} \\
\hline & \multicolumn{2}{|c|}{ Grad 1} & \multicolumn{2}{|c|}{ Grad 2} & \multicolumn{2}{|c|}{ Grad 3} & \multicolumn{2}{|c|}{ Grad 4} & \\
\hline & $\mathbf{F}$ & $\%$ & $\mathbf{F}$ & $\%$ & $\mathbf{F}$ & $\%$ & $\mathbf{F}$ & $\%$ & \\
\hline Gestational Age & & & & & & & & & 0,019 \\
\hline Preterm & 11 & 13.1 & 14 & 16.6 & 49 & 58.3 & 10 & 12 & \\
\hline Full term & 38 & 36.5 & 20 & 19.2 & 42 & 40.4 & 4 & 3.8 & \\
\hline Post term & 1 & 50.0 & 0 & 0 & 1 & 50.0 & 0 & 0 & \\
\hline Total & 50 & 26.5 & 34 & 18.0 & 92 & 48.4 & 14 & 7.4 & \\
\hline Weight (g) & & & & & & & & & 0.003 \\
\hline 540-1499 & 3 & 12.0 & 4 & 16.0 & 14 & 56.0 & 4 & 16.0 & \\
\hline $1500-2500$ & 10 & 16.7 & 9 & 15.0 & 33 & 55.0 & 8 & 13.3 & \\
\hline$>2500$ & 37 & 35.2 & 21 & 20.0 & 45 & 42.9 & 2 & 1.9 & \\
\hline Total & 50 & 26.3 & 34 & 17.9 & 92 & 48.4 & 14 & 7.4 & \\
\hline Use of Oxygen Therapy & & & & & & & & & 0.024 \\
\hline Yes & 23 & 19.8 & 20 & 17.2 & 61 & 52.6 & 12 & 10.3 & \\
\hline No & 27 & 36.5 & 14 & 18.9 & 31 & 41.9 & 2 & 2.7 & \\
\hline Total & 50 & 26.3 & 34 & 17.9 & 92 & 48.4 & 14 & 7.4 & \\
\hline Use of Phototherapy & & & & & & & & & 0.001 \\
\hline Yes & 10 & 13.3 & 15 & 20.0 & 39 & 52.0 & 11 & 14.7 & \\
\hline No & 40 & 34.8 & 19 & 16.5 & 53 & 46.1 & 3 & 2.6 & \\
\hline Total & 50 & 26.3 & 34 & 17.9 & 92 & 48.4 & 14 & 7.4 & \\
\hline Blood Transfusion & & & & & & & & & 0.003 \\
\hline Yes & 4 & 10.8 & 5 & 13.5 & 21 & 56.8 & 7 & 18.9 & \\
\hline No & 46 & 30.1 & 29 & 19.0 & 71 & 46.4 & 7 & 4.6 & \\
\hline Total & 50 & 26.3 & 34 & 17.9 & 92 & 48.4 & 14 & 7.4 & \\
\hline \multicolumn{10}{|l|}{ Conjunctivitis } \\
\hline Yes & 0 & 0 & 0 & 0 & 8 & 100.0 & 0 & 0 & 0.007 \\
\hline No & 50 & 27.5 & 34 & 18.7 & 84 & 46.2 & 14 & 7.7 & \\
\hline Total & 50 & 26.3 & 34 & 17.9 & 92 & 48.4 & 14 & 7.4 & \\
\hline
\end{tabular}

As shown in Table 2, it was verified that there was a statistically significant association between the RRT color gradient and the neonatal variables (gestational age $p=0.019$ ) (birth weight $p=0.003$ ) (use of oxygen therapy $\mathrm{p}=0.024$ ); (phototherapy $\mathrm{p}=0.001$ ) (blood transfusion $p=0.003$ ) and (conjunctivitis $p=0.007$ ). These variables are considered risk factors for the development of vision problems and therefore may have a relationship with the outcome of the red reflex test.

It should also be noted in Table 2, that the sample of this study was composed primarily of full term NBs (104 - 55.03\%) with adequate birth weight (105 $55.26 \%$ ), and, regarding the appearance of the ocular reflex observed, the shades of color referring to the categories Grad 1 and Grad 3 prevailed.

Among those who presented the orange coloration of the ocular reflex (Grad 3) (92-48.4\%), a similar result was observed between the preterm infants (49$58.3 \%$ ) and the full term infants (42 to $40.4 \%$ ). A reflex of a clearer appearance, with little intensity, brown, with less shine, was more often observed in the former, unlike the full term infants.

The results also showed that a higher prevalence of a pale yellow ocular reflex, sometimes with milky white spots over the center (Grad 4), among the premature NBs $(10-12 \%)$ and in those weighing less than $2500 \mathrm{~g}$ (12-14\%).

Among the NBs who underwent oxygen therapy, there was a predominance of the orange reflex (Grad 3) with variations of intensity in $61(52.6 \%)$ of them. From relating the colors of the gradient to the use of oxygen therapy, a significant relationship $(p=0.024)$ was found, although this significance was not evident when a relationship with the duration of oxygen use was sought. 


\section{Discussion}

The red reflex test, although considered a simple examination, requires attention during its realization, as the examiner needs to verify the reflex characteristics carefully and also to observe, in the evaluation, variables ranging from the birth conditions of the infant, to the material environmental and human resources. Other important aspects when performing this test are the acquisition by the examiner of knowledge on the ocular anatomy and the investigation of factors related to the maternal and neonatal history which could have relationships with alterations in vision and with the result of the red reflex.

A study conducted in 2002 which contemplated the ophthalmological evaluation of 667 newborns, conducted in a Rooming-in unit, using the red reflex test (direct ophthalmoscopy), showed that the main ocular alteration found through the test was opacity of the cornea(14).

The literature says that the view of the fundus should be clear, i.e. there should be no opacity in the ocular media, such as dark shadows or black spots that block the red reflex(6). Classification of terms such as "normal or present" were adopted when the reflex in both eyes was similar in color, intensity, clarity and no opacities or white spots existed in any area, either in one or both reflexes observed. The result of "abnormal or absent" was characterized in an opposite way to this ${ }^{(15)}$. Authors also report that the different reflex between the eyes can mean large differences in the refractive power of the eyes, i.e. a degree that can lead to the need for glasses $^{(8)}$.

The findings of the present study denote a color appearance variation in the reflex among the infants with a normal ocular reflex, being sometimes pale, sometimes darker or lighter, sometimes with areas like cobwebs or with the presence of mottling.

Thus, it is clear that the term referred to in literature as "red reflex", although universal, did not always correspond closely to what was found when performing the test where, in reality, color variations from orange to red were often verified, relative to the characteristics of the fundus and retina.

In general, the fundus of premature infants, depending on gestational age, appears pale due to the blood vessels that provide pigmentation to the retina not being fully developed. Hence the fact that a yellow or clear reflex is commonly observed with an ophthalmoscope in preterm infants ${ }^{(6)}$. Other authors also emphasize that in children with low eye pigmentation (Caucasian), the reflex has a red-orange coloration. In children with a more intense eye pigmentation, as in black race infants, the reflex has a darker color (red-maroon)(16).

In premature infants, the remnant of the tunica vasculosa lentis is often visible in front or behind the lens, or even in both positions. The remnant is usually absorbed over time by the children, however, rarely it stays and appears as a complete or partial "cobweb"(17).

A study which examined 47 newborns who presented factors associated with prematurity, low birth weight, hypoxia and ventilatory support, found only one of these NBs had an altered ocular reflex, with eight classified as suspect. In seeking the diagnostic reports of the ophthalmologist, it was found that one of the infants presented total retinal detachment, with a totally opaque reflex observed, and eight developed retinopathy of prematurity(12).

Retinopathy of prematurity (ROP), a leading cause of preventable blindness in children, is a vasoproliferative disorder of the retina that affects premature NBs of low birth weight. It has as risk factors, fluctuations in oxygen levels, septicemia and blood transfusion. At an advanced stage there may be retinal detachment in the NB and detection of the presence of leukocoria, thus becoming a noticeable sign in the red reflex test(18-19).

In another study, in which the sample consisted of 180 newborns hospitalized in a public maternity hospital, $24(13 \%)$ presented a reflex classified as suspect. Contact was sought with those responsible for providing follow-up of the care process of these children, referring them to specialized evaluation by an ophthalmologist collaborator of the study. The visual findings concerning the realization of the red reflex test in this study were confirmed and better detailed with the completion of the fundoscopy and retinal mapping. Other doubtful aspects for the authors regarding the perception of the color of the reflex, when viewed using the ophthalmoscope, were also discussed and considered as variations of normality, i.e. variations in normal retinal development, which is presented in the process of vascularization ${ }^{(2)}$.

It is noteworthy that the preterm infants, due to risk factors that surround them, are found to be more vulnerable to develop alterations of vision when compared to the full term infants. Hence the probable influence of gestational age and birth weight in the results regarding the color of the reflex observed in this study.

Regarding the color gradient and use of oxygen therapy, a statistically significant association was found, although this was not evident when the relationship with 
the duration of oxygen use was sought. This finding may be based on the fact that the sample consisted predominantly of full term infants who required few days of oxygen. However, in another study ${ }^{(20)}$ where the sample was exclusively of premature NBs, a significant association $(p=0.028)$ was found between the result of the RRT and the duration of oxygen therapy.

The literature argues that oxygen, due to being a vasoconstrictor, increases ischemia stimulating the formation of tortuous neovessels. These cause scarring of the retina that can lead to displacement and blocking of the vision. Therefore the less weight the premature infant has, the more likely it is that they will develop ocular problems, such as retinopathy, because they will be exposed to oxygen for longer and subjected to constant fluctuations in their blood pressure(21).

Another study that developed a systematic vision examination with a sample of 114 premature newborns, using the red reflex test, identified $13(11 \%)$ with a suspect reflex. By relating this to neonatal history variables, a statistically significant association was obtained between the outcome of the RRT and the Apgar score in the first minute of life $(p=0.041)^{(10)}$.

Although the literature on the subject is growing, there has been some difficulty to discuss some of the variables presented in more detail, such as the use of phototherapy, blood transfusion and conjunctivitis. However, studies have highlighted, as factors that may make the development of retinal alterations possible, in addition to prematurity and low birth weight, hypoxia or hyperoxia, blood transfusions, infections, and exposure to intense light ${ }^{(18)}$.

In view of the results presented, it is necessary to draw attention to the importance of precautions such as, for example, monitoring, during administration, of the oxygen concentration to prevent its toxic effects on the visual system and the use of eye protection during phototherapy to prevent the incidence of light causing the degeneration of the retina(18,22).

\section{Conclusion}

This study is relevant not only for the promotion of ocular health, but also for the overall health of the child. Finally, the role of vision in normal physical and cognitive development is an indisputable fact, due to the interferences caused by its privation in the quotidian life of the human being. Given this, it is emphasized that to prevent alterations of vision in the infantile population, strategies to promote ocular health should be targeted from the pregnancy, prenatal and neonatal periods.

Due to this being a little explored topic, particularly in nursing studies, it was necessary to use specific literature of other areas to deepen the discussion on the subject.

Based on the data obtained it can be concluded that of the total of newborns evaluated using the red reflex test, the majority presented a normal reflex, noting how the coloration and intensity varied between orange, red and light yellow. Only three newborns revealed a suspect reflex, characterized by yellow with lighter (whitish) spots in the center.

Statistically significant associations were found between the shades of color identified in the gradient for the realization of the red reflex test, and some variables of neonatal history, such as: weight $(p=0.03)$, gestational age $(p=0.019)$, use of oxygen therapy $(p=0.024)$ and phototherapy $(p=0.001)$. Furthermore, as evidenced among premature infants, there was a predominance of the reflex color of orange with low intensity and of light yellow, due to incomplete vascularization of the retina at birth. A similar result occurred in neonates of low weight.

The findings showed that there is not a standard color of the reflex visualized. Although the term used in the literature to refer to the test may wrongly suggest that the reflex is observed only in red, in reality this may present variations depending on several factors, among them the neonatal history variables that will affect the characteristics of the fundus and the retina.

\section{References}

1. Manica NB, Correia ZMS, Macon IM, Telichebesky $\mathrm{N}$, Loch LF. O que os pediatras conhecem sobre afecções oculares na criança? Arq Bras Oftalmol. 2003;66(4):489-92.

2. Aguiar ASC, Cardoso MVLML, Lúcio IML. Teste do reflexo vermelho: forma de prevenção à cegueira na infância. Rev Bras Enferm. 2007;60(5):541-5.

3. Reis PP. Reflexo vermelho. Textos científicos Sociedade Mineira de Pediatria. [internet]. 2005. [acesso: 15 março 2008]. Disponível em: http://www.smp.org.br

4. Graziano RM. Prevenção da cegueira no recémnascido pré-termo. [internet]. 2006. [acesso: 15 março 2009]. Disponível em: http://www.paulomargotto.com. br/index_sub.php?tipo $=27$

5. Sociedade Cearense de Pediatria. Saúde da criança - teste do olhinho precisa ser lei. Boletim Informativo da Sociedade Cearense de Pediatria [Internet]. 2009. 
[acesso em: 03 março 2010]. Disponível em: http:// www.socep.org.br/novo/pdf/infojanfev2009.pdf

6. Jarvis C. Exame físico e avaliação de saúde. 3ed. Rio de Janeiro: Guanabara Koogan; 2002.

7. Weber J. Semiologia: guia prático para a enfermagem. 5ed. Rio de Janeiro: Guanabara Koogan; 2007.

8. Bonotto LB. A importância do Exame de Reflexo Vermelho. [Internet]. 31 ago 2006 [acesso: 20 março 2010]. Disponível em: http://www.oftalmopediatria. com/texto.php.

9. Lúcio IML. Método Educativo para a prática do teste do reflexo vermelho no cuidado ao recém-nascido. [tese de doutorado]. Fortaleza (CE): Departamento de Enfermagem da Universidade Federal do Ceará; 2008. 137 p.

10. Cardoso MVL, Lúcio IML, Aguiar ASC. Aplicação do teste do reflexo vermelho no cuidado neonatal. Rev Rene. 2009;10(1):81-7.

11. Endriss D, Ventura LM, Diniz JR, Celino AC, Toscano J. Doenças oculares em neonatos. Arq Bras Oftalmol. 2002;65(5):551-5.

12. Costa KAB, Cardoso MVLML, Lúcio IML. Avaliação visual em recém-nascidos no ambiente hospitalar. Rev Paul Enferm. 2005;24(2):23-9.

13. Ministério da Saúde (BR). Diretrizes e normas regulamentadoras de pesquisa envolvendo seres humanos: resolução 196/96. Brasília (DF): Conselho Nacional de Saúde; Ministério da Saúde; 1996. 12 p.

14. Wasilewski D, Zago RJ, Bardal AMC, Heusi, TM, Carvalho FP, Maciel LF, et al. Importância da avaliação oftalmológica em recém-natos. J Pediatr. 2002;78(3):209-12.

15. American Academy of Pediatrics. Red reflex examination in neonates, infants, and children. Pediatrics. 2008;122(6):1401-4.

16. Tamura MY, Teixeira LF. Leucocoria e Teste do Reflexo Vermelho. Einstein. 2009; 7(3):376-82.

17. Voughan D, Asbury T, Riordan - Eva P. Oftalmologia geral. 15ed. São Paulo: Atheneu;2003.

18. Margotto PR. Assistência ao recém-nascido de risco. 2ed. Brasília: Hospital Anchieta;2006.

19. Tamez RN, Silva MJP. Enfermagem na UTI neonatal. 4ed. Rio de Janeiro: Guanabara Koogan;2009.

20. Lúcio IML, Cardoso MVLML, Almeida PC. Investigação do reflexo vermelho em recém-nascidos e sua relação com fatores da história neonatal. Rev Esc Enferm USP. 2007;41(2):222-8.

21. Ferreira RC. Retinopatia da prematuridade como diagnosticar. [Internet] [acesso: 10 março 2010]. Disponível em: http://deficienciavisual.com.sapo.pt/sdretinopatiaprematuro.html
22. Ferreira ALC, Nascimento RM, Veríssimo RCSS. Irradiance of phototherapy equipment in maternity wards in Maceió. Rev. Latino-Am. Enfermagem. 2009;17(5):695-700. 